\title{
INFLUENCE OF FARMERS' KNOWLEDGE OF CLIMATE CHANGE ON PRODUCTION OF CITRUS AND TOMATO IN NIGERIA
}

\author{
Adebisi-Adelani O. $^{1}$ and Akeredolu M. ${ }^{2}$
}

Correspondence author: O. Adebisi-Adelani. Email: adelanidotol@yahoo.com

\section{ABSTRACT}

Production is the basis of value-chain which is a key factor in Agricultural Transformation Agenda (ATA) in Nigeria. Thus, for successful production of horticultural crops the importance of climate cannot be overemphasized. Therefore, in this era of climate change there is the need to study farmers' knowledge of climate change and their production level. The study was carried out in Nigeria. Multistage sampling technique was used to arrive at a study population of 441 tomato and citrus farmers. Data were collected using Focus Group Discussions (FGDs), structured interview schedule and secondary data (FAOSTAT). It was analyzed using descriptive statistics (frequencies, percentage and pie charts) and inferential statistics (Pearson Product Moment Correlation). There existed no significant relationship between knowledge level of respondents and change in production of both crops. The reason for this could be that no matter what the level of knowledge one may have on the subject of climate change it does not have anything to do with production, adaptation strategies is the key. Citrus and tomato farmers' adaptation strategies to climate change includes among others crop management, use of varieties resistant to pests and diseases, altering the timing or location of cropping activities, different planting dates and shortened length of growing period. In conclusion climate change has affected the production of horticultural crops therefore for ATA to have a good footing there is the need to focus on the adaptation strategies that can combat the effect of climatic changes.

Key words: Horticultural crops, Horticultural farmers, Climate, Production, Knowledge,

\section{INTRODUCTION}

The major aim of the Agricultural Transformation Agenda (ATA) of Nigeria government is to improve production, processing and marketing of agricultural crops. Agriculture contributed $41.5 \%$ to the GDP in Nigeria; N16.3 billion was realized from export and 99.64 metric tonnes of different staples were produced (Central Bank of Nigeria, 2000). In 2010, it contributed $42 \%$ which is just an increase of $0.5 \%$ between the periods of ten years (CBN, 2010). Relative to other African countries, Nigeria maintains a high rate of food production with a food output index of 157.4 based on 1989-91 records (Food and Agriculture Organisation, 2001). Its index of food output per capita of 199.0 in year 2000, even though fairly marginal, was one of the highest for Africa. Of the 54 countries in Africa, only 24 representing less than 50 percent maintained or slightly improved food production, with Nigeria being the 9 th on the list.

\footnotetext{
${ }^{1}$ Research Scientist (Agricultural extension and Rural Development) in Farming System and Extension Department at National Horticultural Research Institute. P.M. B 5432, Idi-Ishin G.R. A, Ibadan. Oyo State.Nigeria. adelanidotol@yahoo.com

${ }^{2}$ Winrock International
} 
Horticulture is an aspect of agriculture which deals with production, distribution, marketing and utilization of fruits, vegetables, spices, ornamentals and landscape plants. Globally, the importance of today's horticulture industry in fulfilling millennium development goals can be seen in the following areas as enumerated by Warrington (2011) as follows:

- The ongoing provision of protected, healthy and nutritious food,

- The provision of many essential vitamins and minerals, assisting consumers to realize a balanced diet;

- The contributions to economies through export-related activities and the sophistication associated with all elements of the supply chain.

- The viability of rural communities directly through employment and the sustainability of service provision so retaining populations that justify the delivery of services such as health and education;

- Overall wealth generation through the activities of those involved with production, processing, marketing, servicing, and related sectors

- The contributions to leisure, sport and recreational activities through specialised areas such as turf management, landscaping and the creation and management of private and public parks and gardens.

For successful production, horticultural crops require resources like; land, water, sunshine, air, temperature and soil conditions that are natural as well as labour, capital and management or entrepreneurs which are man -made (Oyekale, Bolaji and Olowa, 2009). Among the natural resources, climate is a predominant factor that influences horticultural production. Climate is the synthesis of weather over a given area or location over a period of at least 30 years (Ayoade, 2010).

Changing climate had been attributed directly or indirectly to human activity that alters the composition of the global atmosphere and which led to the natural variability observed over comparable time periods. As implied from the definition therefore, the climate system can vary naturally, and when amplified, becomes a change (Adejuwon, 2004). The knowledge of farmers about climate issues depend on their accessibility to information on weather forecasts, degree of control they have over their resources, among others. Farmers' adequate knowledge and information about climate change will give them ability to adapt at any point in time. Therefore, it is imperative to have an idea of the knowledge of citrus and tomato farmers about climate change.

\section{Objectives}

1. Describe the level of citrus and tomato farmers' production between year 2000 and 2009 in the study area

2. Identify reasons for change in production of citrus and tomato in the study area

3. Examine their level of knowledge on climate change in the study area

4. Assess the respondents' sources of information on climate change in the study area.

\section{HYPOTHESIS}

There is no significant relationship between respondents' knowledge of climate change and change in production 


\section{METHODOLOGY}

The study was carried out in Nigeria. The study population comprises of all citrus and tomato farmers registered with fruits and vegetables farmers Association in Nigeria. Multistage sampling procedure was used to sample a total of 441 farmers in the following order: 1 st stage: Purposive sampling technique was used to select Northcentral, Northeastern, Southeastern and Southwestern zones from the five agricultural zones in Nigeria due to their comparative advantage in horticultural crop production. Second stage: one state each was randomly selected from the selected agricultural zones namely; Benue, Gombe, Imo and Oyo States respectively. The third stage: purposive selection of Agricultural Development Programme (ADP) zones that are known for mass production of selected horticultural crops within the state which are Zone A, Central zone, Okigwe and Oyo zone respectively. Fourth stage: 25\% of ADP blocks within the selected zones were proportionately sampled while the fifth stage involved simple random selection of $50 \%$ of cells within the selected blocks. The last stage involved ten percent proportionate sampling technique of Citrus and Tomato farmers from the generated list of fruits and vegetable producers' association in the communities.

The source of data collection for the study was through primary and secondary sources. The primary sources include: Focused Group Discussions (FGDs) was conducted in all the locations, two in each of the four states using both Tomatoes and Citrus farmers' association. Maximum of twelve participants were selected for each of the FGDs. Quantitative method - Administration of validated interview schedule, yield data of tomato and citrus over the years were also generated from FAOSTAT (2009a, 2009b) which was then used to establish change in production.

\section{RESULTS AND DISCUSSIONS}

\subsection{Respondents' production level of citrus and tomato crops}

Table 1: Distribution of farmers' and FAOSTAT citrus and tomato yield between year 2000 and 2009

\begin{tabular}{|r|r|r|r|r|}
\hline Years & \multicolumn{2}{|c|}{ Tomato yield in tonnes } & \multicolumn{2}{c|}{ Citrus yield in tonnes } \\
\hline & Farmers & \multicolumn{1}{c|}{ FAOSTAT } & Farmers' & FAOSTAT \\
\hline 2000 & 7364.00 & 64448000 & 461742.92 & 50545000 \\
\hline 2001 & 7573.97 & 80902000 & 399731.81 & 42650000 \\
\hline 2002 & 6726.36 & 7000000 & 391337.54 & 43464000 \\
\hline 2003 & 10538.44 & 76505000 & 376364.21 & 45286000 \\
\hline 2004 & 10710.61 & 94599000 & 374596.73 & 47897000 \\
\hline 2005 & 6349.32 & 69764000 & 342532.82 & 58504000 \\
\hline 2006 & 10791.71 & 7000000 & 339922.43 & 45155000 \\
\hline 2007 & 7475.71 & 63470000 & 298815.82 & 45423000 \\
\hline 2008 & 6119.05 & 64188000 & 591229.60 & 47654.00 \\
\hline 2009 & 4319.63 & 59790000 & 237152.82 & 44405.00 \\
\hline
\end{tabular}

Source: Field survey (2011) and FAOSTAT a and b (2009)

The result in Table 1 revealed that over the years, horticultural farmers have been witnessing one type of fluctuation or the other associated with downward trend in their production. 
During FGD, discussants from all the zones stated that they have been witnessing low production. Farmers in the northeastern zone said "that as result of flooding that happened two years ago as at the time of this study, there was very low production experienced in tomatoes industry.' Those citrus farmers in South west said that strange diseases on the crop which they thought might be as a result of irregularity in rainfall. Some mango farmers even expressed their disappointment on mango production to the extent that they have started cutting down some mango trees.

By 2020, yields from rain-fed agriculture in some countries could be reduced by up to 50 percent, increasing food insecurity and hunger (Joto Africa, 2009).

On the other hand, the same Table 1 showed the national figure of the yield of both crops. It is clear that there was decrease in production of the crops over the years.

Table 2: Distribution of change in citrus farmers' crop production $(n=239)$

\begin{tabular}{|l|l|l|l|l|l|l|l|l|l|l|l|}
\hline $\begin{array}{l}\text { Change in } \\
\text { production }\end{array}$ & \multicolumn{2}{l}{$\begin{array}{l}\text { Southwestern } \\
(\mathrm{n}=44)\end{array}$} & \multicolumn{2}{l}{$\begin{array}{l}\text { Southeastern } \\
(38)\end{array}$} & \multicolumn{2}{l}{$\begin{array}{l}\text { Northcentral } \\
(123)\end{array}$} & \multicolumn{2}{l}{$\begin{array}{l}\text { Northeaster } \\
\mathrm{n}(34)\end{array}$} & \multicolumn{2}{l|}{$\begin{array}{l}\text { Total } \\
(239)\end{array}$} \\
\hline & Freq & $\%$ & Freq & $\%$ & Freq & $\%$ & Freq & $\%$ & Freq & $\%$ \\
\hline Increase & 1 & 2.3 & 3 & 9.1 & 13 & 10.3 & 8 & 23.5 & 25 & 10.5 \\
\hline Unchanged & 1 & 2.3 & 10 & 25.0 & 19 & 15.3 & 1 & 3.0 & 31 & 13.0 \\
\hline Decrease & 42 & 95.4 & 25 & 65.9 & 91 & 74.4 & 25 & 73.5 & 183 & 76.5 \\
\hline
\end{tabular}

Source: Field survey (2011)

Table 3: Distribution of change in tomato farmers' crop production $(n=202)$

\begin{tabular}{|l|l|l|l|l|l|l|l|l|l|l|}
\hline $\begin{array}{l}\text { Change in } \\
\text { production }\end{array}$ & \multicolumn{2}{l}{$\begin{array}{l}\text { Southwestern } \\
(\mathrm{n}=66)\end{array}$} & \multicolumn{2}{l|l|l|l|l|}{$\begin{array}{l}\text { Southeastern } \\
(\mathrm{n}=22)\end{array}$} & \multicolumn{2}{l|}{$\begin{array}{l}\text { Northcentral } \\
(\mathrm{n}=47)\end{array}$} & \multicolumn{2}{l|}{$\begin{array}{l}\text { Northeastern } \\
(\mathrm{n}=67)\end{array}$} & \multicolumn{2}{l|}{$\begin{array}{l}\text { Total } \\
(\mathrm{n}=202)\end{array}$} \\
\hline & Freq & $\%$ & Freq & $\%$ & Freq & $\%$ & Freq & $\%$ & Freq & $\%$ \\
\hline Increase & 17 & 25.9 & 0 & 0.0 & 23 & 48.1 & 8 & 12.5 & 48 & 23.8 \\
\hline Unchanged & 2 & 3.7 & 1 & 4.2 & 3 & 7.7 & 4 & 5.6 & 10 & 5.4 \\
\hline Decrease & 47 & 70.4 & 21 & 95.8 & 21 & 44.2 & 55 & 81.9 & 144 & 70.8 \\
\hline
\end{tabular}

Source: Field survey (2011)

The study went further to calculate the rate of change in production of the selected horticultural crops. In general $76.6 \%$ of citrus farmers experienced reduction in yield, $10.5 \%$ had incresase in yield while $13.0 \%$ stated that their yield remains unchanged. In the same vein, $70.8 \%$ of tomato farmers experienced yield reduction, $29.2 \%$ had increased in production while the yield of $5.4 \%$ of respondents remained unchanged (Tables 2 and 3 ).

The same pattern could be seen in each of the zone and for the two crops except for tomato farmers in the Northcentral where $48.1 \%, 44.2 \%$ and $7.7 \%$ have been experiencing increase, decrease and unchanged pattern of production respectively. The successive reduction in the amount of rainfall could result from the effect of climate change. This condition could not be favourable to agricultural production activities except there is increased investment in irrigation schemes in the region as is also required in the Northeast Region (NPAFS, 2009). 


\subsection{Reasons for change in the level of production of selected horticultural crops}

Table 4: Reasons for change in the level of production of citrus crops $(n=239)$

\begin{tabular}{|l|l|l|l|l|l|l|}
\hline $\begin{array}{l}\text { Reasons for change } \\
\text { in production level }\end{array}$ & Most & important & \multicolumn{2}{l|}{ Important } & \multicolumn{2}{l|}{$\begin{array}{l}\text { Least } \\
\text { important }\end{array}$} \\
\hline & Freq & $\%$ & Freq & $\%$ & Freq & $\%$ \\
\hline Input availability & 69 & 29.1 & 66 & 27.5 & 104 & 43.4 \\
\hline Climate change & 137 & 57.1 & 59 & 24.7 & 43 & 18.1 \\
\hline Age of the crop & 41 & 17.0 & 93 & 39.0 & 105 & 44.0 \\
\hline Profitability & 114 & 48.0 & 22 & 9.0 & 103 & 43.0 \\
\hline
\end{tabular}

Source: Field survey (2011)

Table 5: Reasons for change in the level of production of tomato crops $(n=202)$

\begin{tabular}{|l|l|l|l|l|l|l|}
\hline \multicolumn{1}{|c|}{ Reasons } & \multicolumn{2}{c|}{ Most important } & \multicolumn{2}{c|}{ Important } & \multicolumn{2}{c|}{ Least important } \\
\hline & Freq & $\%$ & Freq & $\%$ & Freq & $\%$ \\
\hline Input availability & 88 & 43.6 & 59 & 29.1 & 55 & 27.3 \\
\hline Climate change & 125 & 61.8 & 46 & 22.7 & 31 & 15.5 \\
\hline Age of the crop & 19 & 9.4 & 26 & 12.8 & 157 & 77.8 \\
\hline Profitability & 57 & 28.1 & 28 & 14.0 & 117 & 57.9 \\
\hline
\end{tabular}

Source: Field survey (2011) The results in Table 4 reveals that $29.1 \%, 57.1 \%, 17.0 \%, 48.0 \%$ of respondents stated that input availability for citrus output, climate change on citrus output, age of citrus crop and profitability of citrus enterprise respectively were the most important factors that contribute to low production they have been experiencing in citrus production. In the same vein, (Table 5) 43.6\%, 61.8\%, 9.4\% and $28.1 \%$ of tomato producers stated that input availability on tomatoes output, climate change on tomatoes output, age of tomato crop and profitability of tomato enterprise are the most important factors that contribute to low production which they have been experiencing. The result implies that climate change is the most important factors that are responsible for change in their production. The percentages adduced to climate change were higher compared to other reasons responsible for change in the level of selected horticultural crops production. Thus, climate change could be accounted for reduction in tomato and citrus production in the study area.

\subsection{Categorisation of respondents' knowledge on climate change}

More than half of the respondents $(55.8 \%)$ had high knowledge on climatic change, while $44.2 \%$ had low knowledge (Figure 1). The study went further to see what happens in different zones on knowledge of horticultural farmers about climate change. The same trend was reflected in both southeastern and northcentral where there is high level of knowledge $(20.7 \%$, $41.8 \%$ ) compared to low level of knowledge $(4.6 \%, 34.4 \%)$ respectively. On the contrary, respondents in high knowledge category in the southwestern and northeastern zone were the minority (17.5\% and $20.0 \%$ respondents) while majority (34.4\% and $26.7 \%$ respondents) had low knowledge (Table 6). The result implies that there is generally high knowledge of climatic change effect by respondents. The low knowledge obtained in the southwestern zone may be due to the fact that the climatic condition in the zone does not exhibit a sharp difference compared to other region. This reason may be responsible for low knowledge, awareness and adaptation strategies. 


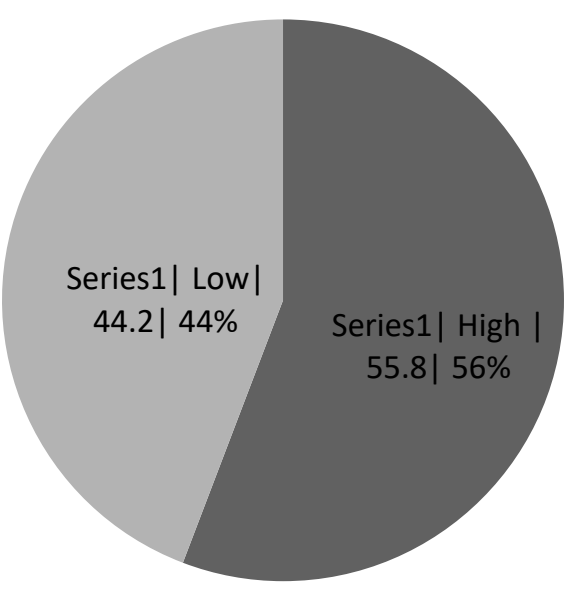

Figure 1: Pie chart showing distribution of respondents' knowledge of climate change Source: Field survey (2011)

Table 6: Distribution of knowledge categorisation of respondents $(n=441)$

\begin{tabular}{|l|l|l|l|l|l|l|l|l|l|l|}
\hline Catergorisation & \multicolumn{2}{|c|}{ SW } & \multicolumn{2}{c|}{ SE } & \multicolumn{2}{c|}{ NE } & \multicolumn{2}{c|}{ NC } & \multicolumn{2}{c|}{ Total } \\
\hline & Freq & Freq & Freq & Freq & Freq & $\%$ \\
\hline Low knowledge & 67 & 34.4 & 9 & 4.6 & 52 & 26.7 & 67 & 34.4 & 195 & 44.2 \\
\hline High knowledge & 43 & 17.5 & 51 & 20.7 & 49 & 20.0 & 103 & 41.8 & 246 & 55.8 \\
\hline Mean=29.0 & SD =5.0 & \multicolumn{3}{|l|}{ Min=5.0 } & \multicolumn{2}{|c|}{ Max=43.0 } & & & & \\
\hline
\end{tabular}

Source: Field survey (2011)

\subsection{Sources of information on climate change}

The result in Table 7 shows that majority $(84.1 \%)$ of the respondents obtained information from radio, family members $(61.7 \%)$, television $(51.5 \%)$, friends $(58.7 \%)$ and social group (51.0\%). Also, information obtained from Global System for Mobile Communications (GSM), newspaper, extension agents, and government agencies accounts for $45.4 \%, 38.5 \%, 38.5 \%$ and $32.2 \%$ respectively. Other sources of information includes National Horticultural Research Institute outlet (12.7\%), Internet (13.2\%), training / capacity building workshops $(16.1 \%)$, Non-Governmental Organisations $(11.6 \%)$, billboard (10.9\%), while fliers and international community were $5.2 \%$ and $5.4 \%$ respectively. This implies that adaptation strategy using radio and television, family members, social groups and friends are likely to produce more result because it is the most prevalent source of information in the study area. The result also reflects the importance of social ties among rural persons in Nigeria as friends and social group as means of information dissemination. This finding is consistent with that of Chapman and Slayman (2002) and Yekini (2010) who recognized that popularity of local radio stations stems from a sense of proximity with the listening community, which other media have not been able to achieve. The implication of this is that radio and television, of all the media, are the ones that can easily reach out to the grassroots communities in the country, this could be due to the fact that both radio and television are accessible across the agricultural zones in Nigeria. As such, it may be necessary for Extension agents to develop programmes on climate issues to disseminate to farmers through the radio and television for wider coverage more so when the ratio of extension agents to farmers is still very large in Nigeria. 
Table 7: Distribution of respondents sources of information on climate change $(n=441)$

\begin{tabular}{|l|l|l|l|l|l|l|}
\hline Information sources & $\mathrm{SW}(\%)$ & $\mathrm{NE}(\%)$ & $\mathrm{NC}(\%)$ & $\mathrm{SE}(\%)$ & TOTAL & RANK \\
\hline Family members & 9.3 & 7.0 & 35.4 & 10.0 & 61.7 & 2nd \\
\hline $\begin{array}{l}\text { National Horticultural } \\
\text { Research Institute }\end{array}$ & 0.7 & 6.1 & 1.4 & 4.5 & 12.7 & 11 th \\
\hline Radio & 18.1 & 21.5 & 33.0 & 10.9 & 84.1 & 1st \\
\hline Television & 9.3 & 17.5 & 17.2 & 7.5 & 51.5 & 4th \\
\hline Newspaper & 0.5 & 16.6 & 15.0 & 6.6 & 38.5 & 6th \\
\hline Internet & 0.2 & 3.2 & 8.8 & 0.9 & 13.2 & 10th \\
\hline $\begin{array}{l}\text { Global System of Mobile } \\
\text { communication }\end{array}$ & 6.8 & 8.4 & 25.9 & 4.3 & 45.4 & 5th \\
\hline Extension agent & 13.6 & 7.5 & 6.6 & 10.9 & 38.5 & 6th \\
\hline Training/capacity building & 5.7 & 4.8 & 2.7 & 2.9 & 16.1 & 9th \\
\hline Friends Governmental & 7.5 & 14.5 & 32.2 & 4.5 & 58.7 & 3rd \\
\hline $\begin{array}{l}\text { Non } \\
\text { Organisations }\end{array}$ & 4.1 & 5.2 & 0.9 & 11.6 & 12th \\
\hline Billboard & 0.7 & 8.2 & 0.7 & 1.4 & 10.9 & 13th \\
\hline Fliers & 1.4 & 2.5 & 0.5 & 0.9 & 5.2 & 15th \\
\hline International community & 0.5 & 2.0 & 1.8 & 1.1 & 5.4 & 14th \\
\hline Government agencies & 7.3 & 11.8 & 8.4 & 4.8 & 32.2 & 8th \\
\hline
\end{tabular}

Source: Field survey (2011)

\section{Test of hypothesis}

\subsection{Test of relationship between respondents' level of knowledge and change in production of citrus and tomato}

The result of the analysis shown in Table 8 indicates that no significant relationship existed between level of knowledge of respondents and change in production of citrus. The result implies that citrus farmers' knowledge of climate change did not influence their production. It is expected that the knowledge a farmer has on climate issues or how regularly and easily he or she can get information such as weather forecasts, plays an important role in the process of building resilience (LEISA, 2008). However, no matter the level of knowledge a person attains about climate change, if he is limited in adaptation and certain coping mechanisms, the production cannot be influenced. The result enables focusing on factors that affects adaptation strategies a real issue.

Table 8: Pearson Product Moment Correlations (PPMC) analysis between level of knowledge of respondents and change in citrus and tomato production

\begin{tabular}{|l|l|l|l|}
\hline & Correlation Value(r) & p-value & Decision \\
\hline Level of knowledge on climate change vs & & & \\
\hline Change in production of citrus farmers & 0.36 & 0.579 & NS \\
\hline Change in production of tomato farmers & 0.35 & 0.620 & NS \\
\hline
\end{tabular}

Source: Field survey (2011) 


\section{CONCLUSIONS AND RECOMMENDATIONS}

Arising from the study, respondents had high level of knowledge on the causes of climate change. Since some of them said that at the time of fruiting of tomatoes, the high incidence of rainfall causes tomato fruits to drop and fall. In the same vein the change in tomato production across the above zones mentioned are also different, in the aspect of yield reduction which is as a result of successive reduction in the amount of rainfall Concerted efforts should be made by relevant agencies (Extension agents, Research Institutes and Hydro Metrologists) in reaching out to horticultural farmers in terms of provision of seeds and seedlings that are drought resistant. Also farmers should be introduced to certain climate smart practices that can enable them to be well adapted to the effects of climatic changes.

\section{REFERENCES}

ADEJUWON, S.A. 2004. Impacts of climate variability and climate change on crop yield in Nigeria. Being the lead paper presented at the stakeholders' workshop on assessment of impacts and adaptation to climate change (AIACC), Conference Centres Obafemi Awolowo University, Ile-Ife 20-21 September 14pp.

AYOADE, J.O. 2010. Climate change issue Causes, Effects and Solutions. In Impact of Climate Change on Food Security in Sub-Saharan Africa. Proceedings of the $14^{\text {th }}$ Annual Symposium of the International Association of Research Scholars and Fellows IITA, Ibadan: $25^{\text {th }}$ February. pp 7-11.

CENTRAL BANK OF NIGERIA (CBN). 2000. Statistical Bulletin; Central Bank of Nigeria Vol. 11 No2.

CENTRAL BANK OF NIGERIA (CBN). 2010. Statistical Bulletin; Central Bank of Nigeria Vol. 11 No2.

WILLEM V.C. 2008. Living Soils Desertification.wordpress.com/2008/09/23/leisa magazine Posted on September 23, 2008 LEISA Magazine, volume 24: 2.

FOOD AND AGRICULTURE ORGANISATION OF THE UNITED NATIONS (FAO). 2001. Production Year Book, Food and Agriculture Organization. Vol. 1.55, Global Environmental Outlook Report, 76 pp; http://www.unep.org/geo/yearbook/.

FOOD AND AGRICULTURE ORGANISATION OF THE UNITED NATIONS STATISTICS (FAOSTAT). 2009a. Food and Agriculture organization of the United Nations; Tomato Production statistic. faostat.fao.org.

FOOD AND AGRICULTURE ORGANISATION OF THE UNITED NATIONS STATISTICS (FAOSTAT). 2009b. Food and Agriculture organization of the United Nations; Citrus Production statistic. faostat.fao.org.

JOTOAFRIKA. 2009. Adapting to climate change in Africa: Editorial. Jotoafrica, Issue 1, July 2009.

NATIONAL PROGRAMME FOR AGRICULTURE AND FOOD SECURITY (NPFAS). 2009. Agricultural Production survey. Federal Ministry of Agriculture and Rural Development.

OYEKALE A. S., Bolaji M.B., Olowa O.W. 2009. The effect of climate change on cocoa production and vulnerability assessment in Nigeria. Med well Agricultural Journal Vol.4 (2): 77- 85.

WARRINGTON, I.J. 2011. Challenges and opportunities for horticulture and priorities for horticultural research at the start of the twenty-first century. Acta Hortic. 916, 59-68. DOI: 10.17660/ActaHortic.2011.916.6. 
S. Afr. J. Agric. Ext.

Vol. 48 No.2, 2020: 83 - 91

http://dx.doi.org/10.17159/2413-3221/2020/v48n2a539
Adebisi-Adelani \& Akeredolu

(License: CC BY 4.0)

YEKINNI, O.T. 2010. Determinants of utilization of information of information communication technologies for agricultural extension delivery in Nigeria. A Ph.D thesis submitted to Agricultural Extension and rural development Department, University of Ibadan, Ibadan.226 pp. 